\title{
Design of Efficient Molecular Catalysts for Synthesis of Cyclic Olefin Copolymers (COC) by Copolymerization of Ethylene and $\alpha$-Olefins with Norbornene or Tetracyclododecene
}

\author{
Weizhen Zhao and Kotohiro Nomura * \\ Department of Chemistry, Faculty of Science and Engineering, Tokyo Metropolitan University, \\ 1-1 Minami Osawa, Hachioji, Tokyo 192-0397, Japan; zwz-911@163.com \\ * Correspondence: ktnomura@tmu.ac.jp; Tel./Fax: +81-42-677-2547 \\ Academic Editor: Keith Hohn \\ Received: 15 October 2016; Accepted: 28 October 2016; Published: 9 November 2016
}

\begin{abstract}
Selected results for the synthesis of cyclic olefin copolymers (COCs) - especially copolymerizations of norbornene (NBE) or tetracyclododecene (TCD) with ethylene and $\alpha$-olefins (1-hexene, 1-octene, 1-dodecene) - using group 4 transition metal (titanium and zirconium) complex catalysts have been reviewed. Half-titanocenes containing an anionic ancillary donor ligand, $\mathrm{Cp}^{\prime} \mathrm{TiX}_{2}(Y)\left(\mathrm{Cp}^{\prime}=\right.$ cyclopentadienyl; $X=$ halogen, alkyl; $Y=$ anionic donor ligand such as aryloxo, ketimide, imidazolin-2-iminato, etc.), are effective catalysts for efficient synthesis of new COCs; ligand modifications play an important role for the desired copolymerization. These new COCs possess promising properties (high transparency, thermal resistance (high glass transition temperature), low water absorption, etc.), thus it is demonstrated that the design of an efficient catalyst plays an essential role for the synthesis of new fine polyolefins with specified properties.
\end{abstract}

Keywords: polymerization; titanium; zirconium; cyclic olefin copolymers; catalyst design; half-titanocene; homogeneous catalysis

\section{Introduction}

Polyolefins such as polyethylene (high-density polyethylene (HDPE), linear low-density polyethylene (LLDPE), etc.) and polypropylene, produced by metal-catalyzed olefin coordination polymerization, are important commercial synthetic polymers in our daily life, and the market capacity still increases every year (especially in China, India, and countries in the Middle East). Synthesis of new polymers with specified functions has been considered to be one of the most attractive targets, and precise control in the copolymerization is thus a feature that usually allows the alteration of the (physical, mechanical, and electronic) properties by varying the ratio of individual components. Design of molecular catalysts attracts considerable attention in terms of synthesis of new polymers; recent progress in the newly designed catalysts offers several new possibilities. Certain cyclic olefin copolymers (COCs) and cyclic olefin polymers (COPs) are amorphous materials with a promising combination of high transparency in the UV-vis region along with humidityand thermal-resistance (high glass transition temperature, $T_{\mathrm{g}}$ ), and extremely low water absorption (excellent water vapor barrier properties) [1-7]. Due to promising characteristics of COCs, these are used as (i) optical applications such as lenses, liquid crystal display light guide panels, and optical films; (ii) materials in medical and diagnostic equipment and electronic devices; and (iii) packaging applications, and many other uses $[8,9]$. In the practical production process, as shown in Scheme 1, methods such as ring-opening metathesis polymerization (ROMP) of multi-COs and subsequent hydrogenation (for COPs), coordination insertion copolymerization of ethylene with COs 
(for COCs), or homopolymerization of COs (for COPs) are generally employed. The copolymerization approach seems to be more promising, because the desired properties (e.g., $T_{\mathrm{g}}$ ) should be tuned by their compositions (e.g., CO content) as well as their microstructures (including tacticity, etc.) [1-7]. COCs are commercialized (as TOPAS ${ }^{\circledR}, \mathrm{APEL}^{\circledR}$, etc.) as ultrapure (applicable to advanced pharma packaging or food-contact films), crystal-clear (glass clear, amorphous), high-barrier (resistant to moisture, alcohols, acids) materials [8,9].

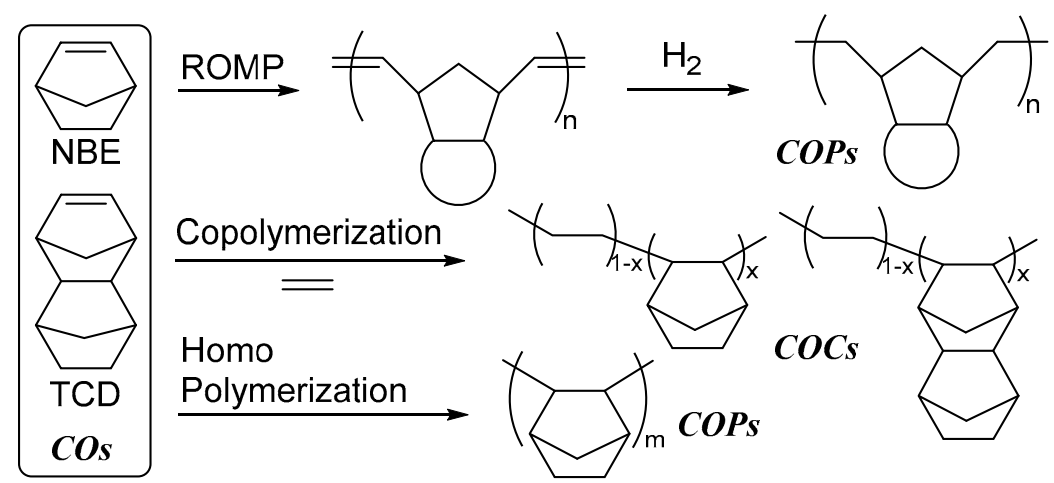

Scheme 1. Typical process for synthesis of COCs (cyclic olefin copolymers) and COPs (cyclic olefin polymers).

Many have reported on ethylene copolymerization with norbornene (NBE) using ordinary metallocenes [10-17], half-titanocenes [18-26], and others [27-30], however, successful examples of the efficient synthesis of random, high molecular weight copolymers with high $T_{\mathrm{g}}$ values (high NBE content) have been limited. Ethylene copolymers with tetracyclododecene (TCD, dimethano-octahydronaphthalene) are also known as promising materials [9], and are produced by using classical Ziegler-type vanadium catalyst systems $\left(\mathrm{VOCl}_{3}, \mathrm{VO}(\mathrm{OEt}) \mathrm{Cl}_{2}-\mathrm{EtAlCl}_{2} \cdot \mathrm{Et}_{2} \mathrm{AlCl}\right.$, etc.) [31]. There have been reports on the copolymerizations using metallocene catalysts [3,32-35] and others [36], however, these catalysts have generally exhibited low catalytic activities and/or less efficient TCD incorporation. For examples, activities (TCD content) by [ $\left.\mathrm{Et}(\mathrm{Ind})_{2}\right] \mathrm{ZrCl}_{2}$ [32], $\left[\mathrm{Ph}_{2} \mathrm{C}(\mathrm{Ind})(\mathrm{Cp})\right] \mathrm{ZrCl}_{2} \quad$ [33], $\quad\left[\mathrm{Ph}_{2} \mathrm{C}(\mathrm{Cp})(\mathrm{Flu})\right] \mathrm{ZrCl}_{2} \quad$ [33], $\quad\left[\mathrm{Me}_{2} \mathrm{C}\left(3-\mathrm{MeC}_{5} \mathrm{H}_{3}\right)(\mathrm{Flu})\right] \mathrm{ZrCl}_{2} \quad$ [3], $\left[\mathrm{Me}_{2} \mathrm{C}\left(3-{ }^{t} \mathrm{BuC}_{5} \mathrm{H}_{3}\right)(\mathrm{Flu})\right] \mathrm{ZrCl}_{2}$ [3] were $25 \mathrm{~kg}$-polymer/mol-Zr.h $(35 \mathrm{~mol} \%), 31(85 \mathrm{~mol} \%$ at $\left.90{ }^{\circ} \mathrm{C}\right), 24$ (68), $1.3(40), 0.4(44)$, and respectively. Design of molecular catalysts for synthesis of new polymers with specified functions is one of the most attractive targets in the field of catalysis, polymer chemistry, and organometallic chemistry [37-48]. In this minireview, reported examples of copolymerization of COs (NBE, TCD) with olefins (ethylene, propylene, 1-hexene, 1-octene, etc.), including our efforts using so-called nonbridged half-titanocene catalysts [39,41,45], $\mathrm{Cp}^{\prime} \mathrm{TiX}_{2}(Y)$ $\left(\mathrm{Cp}^{\prime}=\right.$ cyclopentadienyl; $\mathrm{X}=$ halogen, alkyl etc.; $Y=$ anionic ancillary donor such as aryloxy, ketimide, imidazolin-2-iminato, etc.), have been summarized.

\section{Copolymerization of Ethylene with Norbornene (NBE), Tetracyclododecene (TCD) by Titanium and Zirconium Complex Catalysts}

As described in the introduction, many have reported on ethylene copolymerization with norbornene (NBE) [10-30], however, successful examples of the efficient synthesis of random, high molecular weight copolymers with high $T_{\mathrm{g}}$ values (high NBE content) have been limited. Selected complex catalysts employed for the copolymerization are shown in Scheme 2, and selected typical results are summarized in Table 1. 

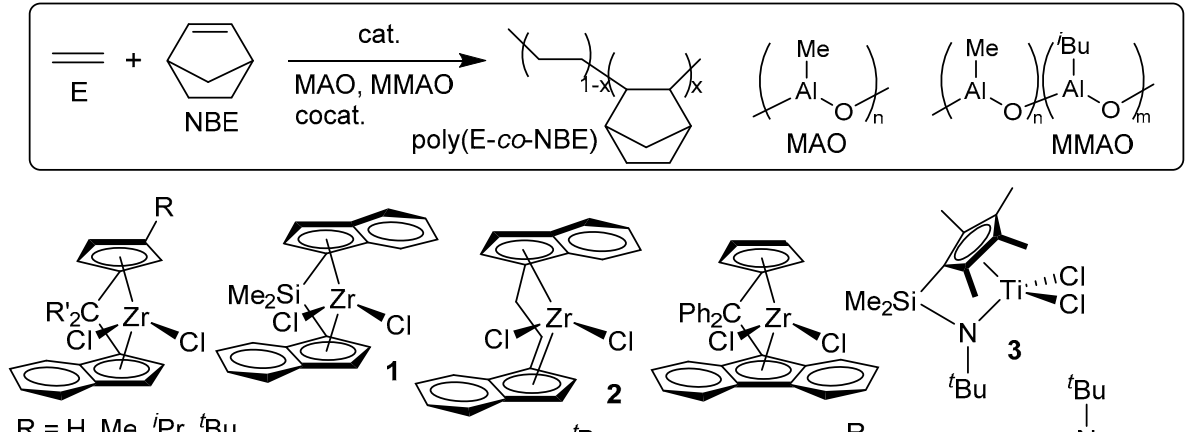

$\mathrm{R}=\mathrm{H}, \mathrm{Me},{ }^{i} \mathrm{Pr},{ }^{t} \mathrm{Bu}$

$\mathrm{R}^{\prime}=\mathrm{Me}, \mathrm{Ph}$<smiles></smiles>

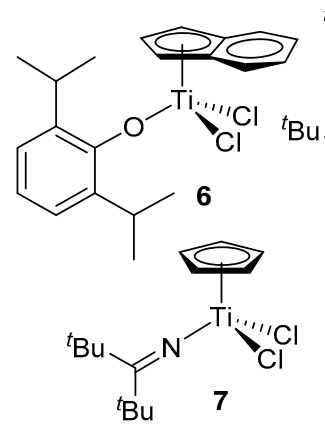

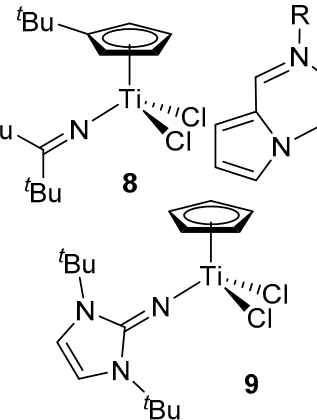<smiles>CC(C)c1cc(C(C)C)n(P(Cl)(Cl)(Cl)c2cccc(Br)c2)n1</smiles>

Scheme 2. Selected complex catalysts for copolymerization of ethylene with norbornene [1-30].

Table 1. Copolymerization of ethylene (E) with norbornene (NBE) by $\left[\mathrm{Me}_{2} \mathrm{Si}(\text { indenyl })_{2}\right] \mathrm{ZrCl}_{2}$ (1), $\left[\mathrm{Me}_{2} \mathrm{Si}\left(\mathrm{C}_{5} \mathrm{Me}_{4}\right)\left(\mathrm{N}^{t} \mathrm{Bu}\right)\right] \mathrm{TiCl}_{2}$ (3), $\mathrm{Cp}^{\prime} \mathrm{TiCl}_{2}\left(\mathrm{O}-2,6-{ }^{i} \mathrm{Pr}_{2} \mathrm{C}_{6} \mathrm{H}_{3}\right)\left(\mathrm{Cp}^{\prime}=\mathrm{C}_{5} \mathrm{Me}_{5}\left(\mathrm{Cp}^{*}\right.\right.$, 5), indenyl (6)), $\mathrm{Cp}^{\prime} \mathrm{TiCl}_{2}\left(\mathrm{~N}=\mathrm{C}^{t} \mathrm{Bu}_{2}\right) \quad\left(\mathrm{Cp}^{\prime}=\mathrm{Cp}(7),{ }^{t} \mathrm{BuC}_{5} \mathrm{H}_{4}\right.$ (8)), $\mathrm{CpTiCl}_{2}\left[1,3-{ }^{\mathrm{t}} \mathrm{Bu}_{2}(\mathrm{CHN})_{2} \mathrm{C}=\mathrm{N}\right]$ (9), $\left({ }^{t} \mathrm{BuC}_{5} \mathrm{H}_{4}\right) \mathrm{TiCl}_{2}\left(3,5-{ }^{i} \mathrm{Pr}_{2} \mathrm{C}_{3} \mathrm{HN}_{2}\right)(\mathbf{1 0})-\mathrm{MAO}$ catalysts. ${ }^{\mathrm{a}}$

\begin{tabular}{|c|c|c|c|c|c|c|c|c|c|c|}
\hline $\begin{array}{c}\text { Cat. } \\
\text { ( } \mu \mathrm{mol})\end{array}$ & $\begin{array}{c}\text { Temp./ } \\
{ }^{\circ} \mathrm{C}\end{array}$ & $\begin{array}{l}\text { Time/ } \\
\text { min }\end{array}$ & E/atm & $\mathrm{NBE}^{\mathrm{b}} / \mathrm{M}$ & {$[\mathrm{NBE}]_{0} /[\mathrm{E}]_{0}{ }^{\mathrm{c}}$} & Activity $^{\mathrm{d}}$ & $M_{\mathrm{n}}^{\mathrm{e}} \times 10^{-4}$ & $M_{\mathrm{w}} / M_{\mathrm{n}}^{\mathrm{e}}$ & $\begin{array}{c}\text { NBE } \\
\mathrm{f} / \mathrm{mol} \%\end{array}$ & Ref. \\
\hline $1(0.10)$ & 25 & 10 & 4 & 0.2 & 0.41 & 28,860 & 23.1 & 2.02 & 10.8 & 24 \\
\hline $3(0.50)$ & 25 & 10 & 4 & 0.2 & 0.41 & 2460 & 21.1 & 1.88 & 9.6 & 24 \\
\hline $3(0.50)$ & 25 & 10 & 4 & 1.0 & 2.04 & 2000 & 12.8 & 2.15 & 26.5 & 24 \\
\hline $5(0.2)$ & 25 & 10 & 4 & 0.2 & 0.41 & 6540 & 57.9 & 1.61 & 8.2 & 24 \\
\hline $6(0.5)$ & 25 & 10 & 4 & 1.0 & 2.04 & 2300 & 5.87 & 1.82 & 35.2 & 24 \\
\hline $7(0.02)$ & 25 & 10 & 4 & 0.2 & 0.41 & 21,600 & 70.6 & 1.85 & 17.8 & 24 \\
\hline $7(0.02)$ & 25 & 10 & 4 & 1.0 & 2.04 & 40,200 & 71.9 & 2.92 & 40.7 & 24 \\
\hline $7(0.02)$ & 25 & 20 & 4 & 1.0 & 2.04 & 60,150 & 53.4 & 2.11 & 41.5 & 24 \\
\hline $7(0.02)$ & 25 & 30 & 4 & 1.0 & 2.04 & 59,700 & 61.3 & 2.18 & 41.0 & 24 \\
\hline $7(0.02)^{g}$ & 25 & 10 & 4 & 1.0 & 2.04 & 42,300 & 35.5 & 2.42 & 41.8 & 24 \\
\hline $7(0.02)$ & 40 & 10 & 4 & 1.0 & 2.45 & 48,900 & 62.0 & 2.37 & 45.9 & 24 \\
\hline $7(0.02)$ & 60 & 10 & 4 & 1.0 & 3.02 & 194,000 & 47.5 & 2.20 & 51.2 & 24 \\
\hline $7(0.02)$ & 80 & 10 & 4 & 1.0 & 3.94 & 133,000 & 33.8 & 2.34 & 61.7 & 24 \\
\hline $8(0.01)$ & 25 & 10 & 4 & 1.0 & 2.04 & 68,400 & 62.4 & 2.78 & 38.2 & 6 \\
\hline $8(0.10)^{g}$ & 25 & 10 & 2 & 5.0 & 20.6 & 4980 & 14.2 & 1.94 & 64.8 & 6 \\
\hline $9(0.20)$ & 25 & 10 & 4 & 1.0 & 2.04 & 6180 & 108 & 2.53 & 31.4 & 26 \\
\hline $9(0.20)$ & 80 & 10 & 4 & 1.0 & 3.94 & 5780 & 80.0 & 2.35 & 36.9 & 26 \\
\hline $9(1.0)$ & 50 & 10 & 2 & 5.0 & 27.3 & 1820 & 13.8 & 1.85 & 55.5 & 26 \\
\hline $10(0.25)$ & 25 & 10 & 5 & 0.5 & 0.82 & 5170 & 126 & 2.32 & 37.2 & 26 \\
\hline $10(0.25)$ & 25 & 10 & 5 & 1.0 & 1.63 & 3470 & 89.2 & 2.63 & 43.9 & 25 \\
\hline
\end{tabular}

${ }^{a}$ Conditions: toluene + norbornene (NBE) total $50 \mathrm{~mL}$, ethylene $4 \mathrm{~atm}$, methylaluminoxane (MAO) white solid 0.5-3.0 mmol; ${ }^{\mathrm{b}} \mathrm{NBE}$ concentration charged $(\mathrm{mmol} / \mathrm{mL}) ;{ }^{\mathrm{c}}$ initial molar ratio; ${ }^{\mathrm{d}}$ activity in kg-polymer $/ \mathrm{mol}-\mathrm{M} \cdot \mathrm{h}$ $(M=\mathrm{Ti}, \mathrm{Zr}) ;$ e gel permeation chromatography (GPC) data in $o$-dichlorobenzene vs polystyrene standards; ${ }^{\mathrm{f}} \mathrm{NBE}$ content (mol \%) estimated by ${ }^{13} \mathrm{C}$ NMR spectra; $\mathrm{g}$ modified MAO (MMAO)-3A-T, $\mathrm{Me} /{ }^{i} \mathrm{Bu}=2.33$, $3.0 \mathrm{mmol} ;{ }^{\mathrm{h}} \mathrm{MMAO}-3 \mathrm{~A}-\mathrm{H}, \mathrm{Me} /{ }^{i} \mathrm{Bu}=2.67,3.0 \mathrm{mmol} ;{ }^{i}$ toluene + NBE total $10 \mathrm{~mL}$. 
In the copolymerization of ethylene with NBE using metallocene (exemplified as 1) and linked half-titanocene (3), the activity generally decreases upon increasing the NBE content (NBE concentration charged). Aryloxo-modified half-titanocenes (exemplified as 5 and 6) have been known as effective catalysts in ethylene copolymerization, not only with $\alpha$-olefin, but also with sterically encumbered olefins and cyclic olefins [39,41,45]; an efficient catalyst for the desired copolymerization can be tuned by the cyclopentadienyl fragment [39,41]. The indenyl-aryloxo analogue (6) showed efficient NBE incorporation with high catalytic activity, whereas the C $\mathrm{p}^{*}$-aryloxo analogue (5) showed less efficient NBE incorporation than $6[22,23]$, however, both the activity and the $M_{n}$ value decreased upon increasing the NBE content. The $C p^{\prime}$-pyrazolato analogue (10) exhibited efficient NBE incorporation with rather low NBE concentration (Table 1) to yield ultrahigh molecular weight copolymers with unimodal molecular weight distributions, but the activity decreased upon increasing the NBE concentration [25].

We demonstrated that the $\mathrm{Cp}$-ketimide analogue, $\mathrm{CpTiCl}_{2}\left(\mathrm{~N}=\mathrm{C}^{t} \mathrm{Bu}_{2}\right)(7)$, exhibited remarkable catalytic activities, and a decrease in the activity was not observed, even after $30 \mathrm{~min}$ [24]. The activity increased upon increasing the initial NBE concentration, whereas, as described above, a decrease in activity was observed in other catalysts upon increasing NBE concentration. The NBE content in the copolymers was thus higher than those prepared by other catalysts under the same conditions. It is noteworthy that neither activity nor NBE incorporation were strongly affected by the Al cocatalyst employed (methylaluminoxane (MAO), modified MAOs (MMAOs)), a fact that is in distinct contrast to that reported for the copolymerization by $\left[\mathrm{Me}_{2} \mathrm{Si}\right.$ (fluorenyl) $\left.\left(\mathrm{N}^{t} \mathrm{Bu}\right)\right] \mathrm{TiMe}_{2}(4)$ in which both the catalytic activity and NBE incorporation are highly dependent upon the Al cocatalyst employed [21]. Both the activity (of 7) and the NBE content in the copolymer increased at a higher temperature $\left(40-80^{\circ} \mathrm{C}\right)$, and the resultant copolymers possessed high molecular weights with unimodal molecular weight distributions $\left(M_{n}=3.38 \times 10^{5}\right.$ to $\left.6.20 \times 10^{5}, M_{\mathrm{w}} / M_{n}=2.20-2.37\right)$ [24]. The efficient synthesis of high molecular weight copolymers with high NBE content $(58.8-73.5 \mathrm{~mol} \%)$ is possible upon increasing the NBE concentration at low ethylene pressure ( $2 \mathrm{~atm})$. This may also be explained by the fact that 7 showed remarkable catalytic activity for NBE homopolymerization. The resultant polymers possessed uniform compositions, confirmed by differential scanning calorimetry (DSC) thermograms as well as gel permeation chromatography (GPC) traces, and a linear relationship between glass transition temperatures and NBE content in the resultant poly(ethylene-co-NBE)s was observed [22-25].

The $\mathrm{Cp}^{\prime}$-imidazolin-2-iminato analogue exhibits remarkable catalytic activities for ethylene (co)polymerization [49-51], and ethylene/NBE copolymerization by $\mathrm{CpTiCl}_{2}\left[1,3-{ }^{\mathrm{t}} \mathrm{Bu}_{2}(\mathrm{CHN})_{2} \mathrm{C}=\mathrm{N}\right]$ (9) afforded ultrahigh molecular weight copolymer with efficient NBE incorporation and a catalytic activity that did not decrease at $80^{\circ} \mathrm{C}$ [26]; both the activity and the $M_{n}$ value decreased upon increasing the NBE concentration under low ethylene pressure. Although the observed activities by 9 were lower than those by 7,9 seems to be a promising candidate as an efficient catalyst that affords high molecular weight polymers at high temperature. In contrast to the imidazolin-2-iminato analogue [26], the $\mathrm{Cp}^{\prime}$-imidazolidin-2-iminato analogue showed less efficient NBE incorporation in the ethylene/NBE copolymerization [52]. In these catalysts, a significant effect of the ligand substituents on both the catalytic activity and the comonomer incorporation was observed.

As described above, ethylene copolymers with tetracyclododecene (TCD, dimethanooctahydronaphthaline) and poly(ethylene-co-TCD)s are promising materials, possessing higher glass transition temperatures compared to poly(ethylene-co-NBE)s with the same cyclic olefin content; catalyst(s) development/design for the efficient copolymerization (high catalytic activity and efficient TCD incorporation) has thus been a promising target in the field of catalysis and polymer chemistry. These are produced by using classical Ziegler-type vanadium catalyst systems ( $\mathrm{VOCl}_{3}, \mathrm{VO}(\mathrm{OEt}) \mathrm{Cl}_{2}-\mathrm{EtAlCl}_{2} \cdot \mathrm{Et}_{2} \mathrm{AlCl}$, etc.) [9,31]. In contrast to many reports of the ethylene/NBE copolymerization [1-30], there have been reports for the copolymerization using metallocene catalysts (Scheme 3) [3,32-35] and others [36], however, these catalysts generally exhibited low catalytic activities and/or less efficient TCD incorporation [35]. 


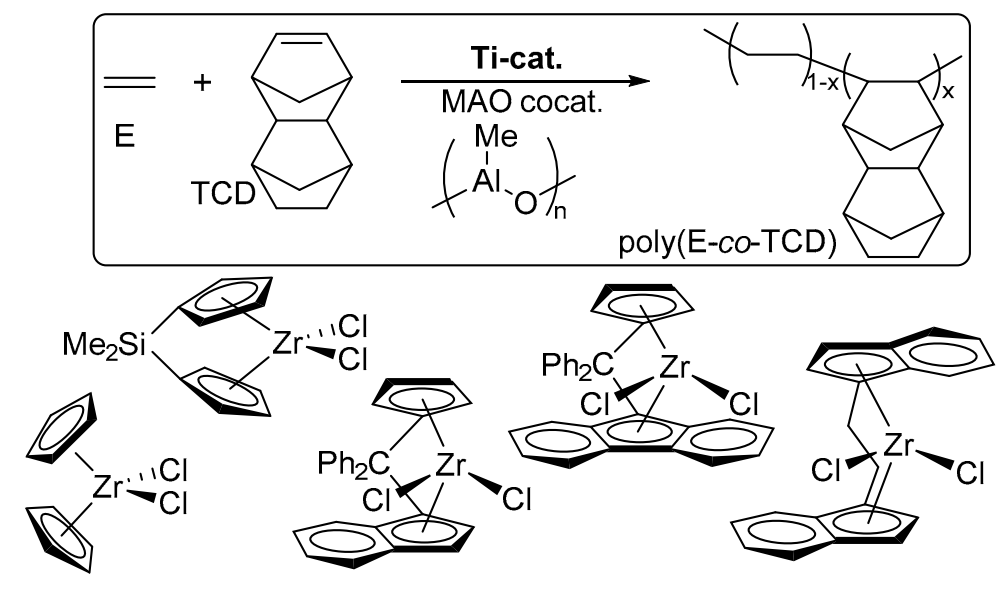

Scheme 3. Reported metallocene catalysts for copolymerization of ethylene with tetracyclododecene (TCD) [3,32-35].

More recently, we realized that the ketimide-modified half-titanocenes, which are effective catalysts for ethylene copolymerization with NBE [24], especially the $\left({ }^{t} \mathrm{BuC}_{5} \mathrm{H}_{4}\right) \mathrm{TiCl}_{2}\left(\mathrm{~N}=\mathrm{C}^{t} \mathrm{Bu}_{2}\right)$ (8)-MAO catalyst, exhibited remarkable catalytic activities and efficient comonomer incorporation in ethylene/TCD copolymerization, affording high molecular weight polymers with uniform molecular weight distributions (Table 2) [53]. The activity of 8 was significantly higher than that of the $\mathrm{Cp}$ analogue (7), whereas the activity of the $C p$ analogue (7) was much higher than that of 8 for $\alpha$-olefin/TCD copolymerization [54]. The resultant polymers prepared by 7- or 8-MAO catalysts possess high molecular weights with uniform molecular weight distributions. The resultant polymers possess sole glass transition temperatures $\left(T_{\mathrm{g}}\right)$, suggesting that these are poly(ethylene-co-TCD)s with uniform compositions.

Table 2. Copolymerization of ethylene with tetracyclododecene (TCD) by $\mathrm{Cp}^{\prime} \mathrm{TiCl}_{2}\left(\mathrm{~N}=\mathrm{C}^{t} \mathrm{Bu}_{2}\right)$

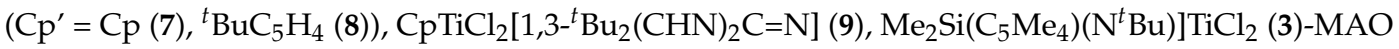
catalysts $^{\mathrm{a}}$.

\begin{tabular}{|c|c|c|c|c|c|c|c|}
\hline $\mathrm{Ti} / \mu \mathrm{mol}$ & $\mathrm{TCD}^{\mathrm{b} / \mathrm{mol} / \mathrm{L}}$ & temp. $/{ }^{\circ} \mathrm{C}$ & Activity $^{c}$ & $M_{\mathrm{n}}^{\mathrm{d}} \times 10^{-5}$ & $M_{\mathrm{w}} / M_{\mathrm{n}}^{\mathrm{d}}$ & $T_{\mathrm{g}}^{\mathrm{e}}\left(T_{\mathrm{m}}{ }^{\mathrm{e}}\right) /{ }^{\circ} \mathrm{C}$ & $\mathrm{TCD}^{\mathrm{f}} / \mathrm{mol} \%$ \\
\hline $3(0.05)$ & 1.0 & 25 & 13,900 & 14.3 & 1.58 & 56 & - \\
\hline $7(0.4)$ & 1.0 & 25 & 1510 & 2.33 & 1.56 & - & - \\
\hline $7(0.8)$ & 2.0 & 25 & 1650 & 1.92 & 1.41 & 150 & \\
\hline $8(0.02)$ & 1.0 & 25 & 43,700 & 5.88 & 1.60 & 108 & 25.6 \\
\hline $8(0.02)$ & 2.0 & 25 & 23,900 & 6.38 & 1.50 & 153 & 32.8 \\
\hline $8(0.02)$ & 2.0 & 40 & 27,800 & 6.43 & 1.67 & 170 & $33.5^{\mathrm{g}}$ \\
\hline $8(0.02)$ & 2.0 & 60 & 33,300 & 6.53 & 1.72 & 177 & 35.3 \\
\hline $8(0.02)$ & 3.0 & 25 & 16,800 & 6.43 & 1.61 & 171 & $33.6^{\mathrm{g}}$ \\
\hline $8(0.02)$ & 4.0 & 60 & 22,400 & 6.08 & 1.61 & 203 & 36.7 \\
\hline $9(0.2)$ & 1.0 & 25 & 6680 & 4.68 & 1.77 & $160(108)^{g}$ & - \\
\hline
\end{tabular}

a Polymerization conditions: toluene and TCD total $30 \mathrm{~mL}$, ethylene $6 \mathrm{~atm}, 10 \mathrm{~min}$, d-MAO (prepared by removing toluene and $\mathrm{AlMe}_{3}$ from the ordinary MAO) $3.0 \mathrm{mmol}$; ${ }^{\mathrm{b}}$ initial monomer concentration; ${ }^{\mathrm{c}}$ activity $=\mathrm{kg}$-polymer $/ \mathrm{mol}-\mathrm{Ti} \cdot \mathrm{h} ;{ }^{\mathrm{d}}$ GPC data in $\mathrm{o}$-dichlorobenzene vs polystyrene standards; ${ }^{\mathrm{e}}$ measured by differential scanning calorimetry (DSC) thermograms; ${ }^{\mathrm{f}}$ estimated from ${ }^{13} \mathrm{C}$ NMR spectra; ${ }^{\mathrm{g}}$ estimated on the basis of the plots of $T_{\mathrm{g}}$ and TCD content.

In contrast, attempted copolymerizations by the imidazolin-2-iminato analogues, $\mathrm{CpTiCl}_{2}\left[1,3-{ }^{\mathrm{t}} \mathrm{Bu}_{2}(\mathrm{CHN})_{2} \mathrm{C}=\mathrm{N}\right]\left(\mathrm{Cp}^{\prime}={ }^{t} \mathrm{BuC}_{5} \mathrm{H}_{4}, \mathrm{Cp}(9)\right)$, afforded polymers possessing melting temperature (ca. $110{ }^{\circ} \mathrm{C}$, probably corresponding to polyethylene with low TCD content) and/or glass transition temperature (ca. $160{ }^{\circ} \mathrm{C}$, corresponding to ethylene/TCD copolymer containing moderate TCD content). These suggest that the resultant polymers are a mixture of at least two compositions and that the catalytically active species are not uniform during the polymerization. 
The linked half-titanocene (3) exhibited high catalytic activity under the same conditions, affording a high molecular weight copolymer with low TCD content (estimated by the $T_{\mathrm{g}}$ value).

Note that the activity of the 8-MAO catalyst increased at higher temperature (activity of 8: $23,900 \mathrm{~kg}$-polymer/mol-Ti.h $\left.\left(25^{\circ} \mathrm{C}\right)<27,800\left(40^{\circ} \mathrm{C}\right)<33,300\left(60^{\circ} \mathrm{C}\right)\right)$ upon increasing the TCD content in the copolymers. As observed in poly(ethylene-co-NBE)s, a linear relationship between the TCD content and glass transition temperature $\left(T_{\mathrm{g}}\right)$ was observed, suggesting that the resultant copolymers possess uniform composition. Since the reported metallocene catalysts showed low catalytic activities (and/or had less efficient TCD incorporations), and ordinary Ziegler-type vanadium catalyst systems are generally sensitive to polymerization temperature, the present catalyst would be a promising candidate (as a thermally robust catalyst) for efficient synthesis of ethylene/TCD copolymers (highly transparent, thermal-resistant materials).

\section{Copolymerization of $\alpha$-Olefin with Norbornene (NBE) or Tetracyclododecene (TCD) by Half-Titanocene Catalysts}

As described in the introduction, reported examples for copolymerization of NBE with $\alpha$-olefin have been limited [54-64], probably due to the difficulty of $\alpha$-olefin insertion after NBE incorporation by linked-metallocene catalysts, as pointed out in a previous review by Tritto et al. [5]. In fact, both the catalytic activity and the $M_{n}$ values decreased upon increasing the $\alpha$-olefin content in the NBE/1-octene copolymerization using $\left[\mathrm{H}_{2} \mathrm{C}\left(\mathrm{Me}_{2} \mathrm{C}_{5} \mathrm{H}_{2}\right)_{2}\right] \mathrm{ZrCl}_{2}$ [58]. As one exception, the fluorenyl-based half-titanocenes, exemplified by $\left[\mathrm{Me}_{2} \mathrm{Si}\right.$ (fluorenyl)-(N $\left.\left.{ }^{t} \mathrm{Bu}\right)\right] \mathrm{TiMe}_{2},($ Flu-CGC, 4$)$ reported by Shiono et al. afforded copolymers of NBE not only with propylene [60,61], but also with $\alpha$-olefin (1-hexene, 1-octene, and 1-decene) [62,63], and the resultant copolymers possessed narrow molecular weight distributions because of the nature of livingness, as observed in the NBE $[64,65]$ and the propylene polymerizations [66]. Both the activity (especially) and the $\alpha$-olefin content were affected by the ligand substituents and cocatalyst employed [60-63]. Examples of copolymerization of TCD with $\alpha$-olefins have not been reported, so far [67].

We recently reported that the ketimide-modified half-titanocenes, $\mathrm{CpTiCl}_{2}\left(\mathrm{~N}=\mathrm{C}^{t} \mathrm{Bu}_{2}\right)(7)$, which are effective catalysts for ethylene/NBE copolymerization [24], showed high catalytic activity with efficient NBE incorporation in the copolymerization of NBE with $\alpha$-olefins (1-hexene and 1-octene), affording high molecular weight polymers with uniform molecular weight distributions and compositions (Scheme 4) [54]. Selected results are summarized in Table 3.

As shown in Table 3, the copolymerizations of NBE with 1-hexene (HX), 1-octene (OC), and 1-dodecene (DD) by 7- or 8-MAO catalysts afforded high molecular weight copolymers with unimodal molecular weight distributions and with uniform compositions confirmed by DSC theromograms (observed as a sole glass transition temperature $\left(T_{\mathrm{g}}\right)$ ). Moreover, the $T_{\mathrm{g}}$ values increased upon increasing the NBE content, as estimated by ${ }^{13} \mathrm{C}$ NMR spectra. The copolymerization of NBE with $\mathrm{HX}$ by $\left({ }^{t} \mathrm{BuC}_{5} \mathrm{H}_{4}\right) \mathrm{TiCl}_{2}\left(\mathrm{~N}=\mathrm{C}^{t} \mathrm{Bu}_{2}\right)(8)$-MAO catalyst proceeded with moderate catalytic activity that is comparable to that of the reported Flu-CGC (4)- $\mathrm{Ph}_{3} \mathrm{CB}\left(\mathrm{C}_{6} \mathrm{~F}_{5}\right)_{4}$ catalyst [62], and the activity increased upon increasing the NBE concentration charged. The $C p$ analogue (7) showed $>10$ times higher activity and better NBE incorporation than the ${ }^{t} \mathrm{BuC}_{5} \mathrm{H}_{4}$ analogue (8) under the same conditions, and the $T_{\mathrm{g}}$ values (corresponding to NBE contents in the resultant copolymers) were not affected by the kind of Al cocatalyst employed (MAO or MMAO). Good correlation between $T_{\mathrm{g}}$ values and NBE content in poly(NBE-co-HX)s was observed, irrespective of the cyclopentadienyl fragment (Figure 1a); this would be in distinct contrast to that reported previously (exemplified by 4), in which the plots (slope) are affected by substituents on the fluorenyl ligand as well as by the cocatalyst employed [62,63]. Similarly, the copolymerization of NBE with OC by 7- or 8-MAO catalysts proceeded with high catalytic activities, and both the activity and the NBE incorporation by 7 were higher than that by 8 under the same conditions. The activity of $\mathbf{7}$ (on the basis of polymer yields) was not strongly affected by the initial NBE/OC feed ratios, whereas the activity of $\mathbf{8}$ increased upon increasing the initial NBE concentration charged under certain conditions. Similar trends (for both 
the activities and NBE incorporations) were observed in the copolymerization of NBE with DD. Good linear relationships between $T_{\mathrm{g}}$ values and NBE content in poly(NBE-co-HX)s (Figure 1a) and poly(NBE-co-OC)s (Figure 1b) were observed, irrespective of kind of titanium catalysts (7 and 8) employed. The $T_{\mathrm{g}}$ values were affected by the $\alpha$-olefin employed; $T_{\mathrm{g}}$ values with the same NBE content increased in the following order: poly(NBE-co-DD) $<$ poly (NBE-co-OC)s $<$ poly $(\mathrm{NBE}-c o-\mathrm{HX}) \mathrm{s}$ (Figure 1b). Moreover, the NBE incorporation was not strongly affected by the nature of $\alpha$-olefin employed, and relatively linear correlations between NBE content in the copolymers and NBE/ $\alpha$-olefin feed molar ratios were observed, irrespective of kind of $\alpha$-olefins employed, especially under high $\mathrm{NBE} / \alpha$-olefin feed ratio conditions. Synthesis of high molecular weight copolymers of (long chain) $\alpha$-olefins with various NBE content (with uniform molecular weight distributions and compositions) can be achieved by adopting these catalyses. The activity of $\mathbf{7}$ increased at high temperature, especially at $50{ }^{\circ} \mathrm{C}$, and no significant differences in the $T_{\mathrm{g}}$ values (NBE content) in the resultant copolymers were observed by varying the temperature $\left(25-70^{\circ} \mathrm{C}\right)$. This would suggest that there has not been a significant temperature dependence observed for the NBE incorporation, as has been observed in ethylene / $\alpha$-olefin copolymerization by ordinary ansa metallocene catalysts $[68,69]$.

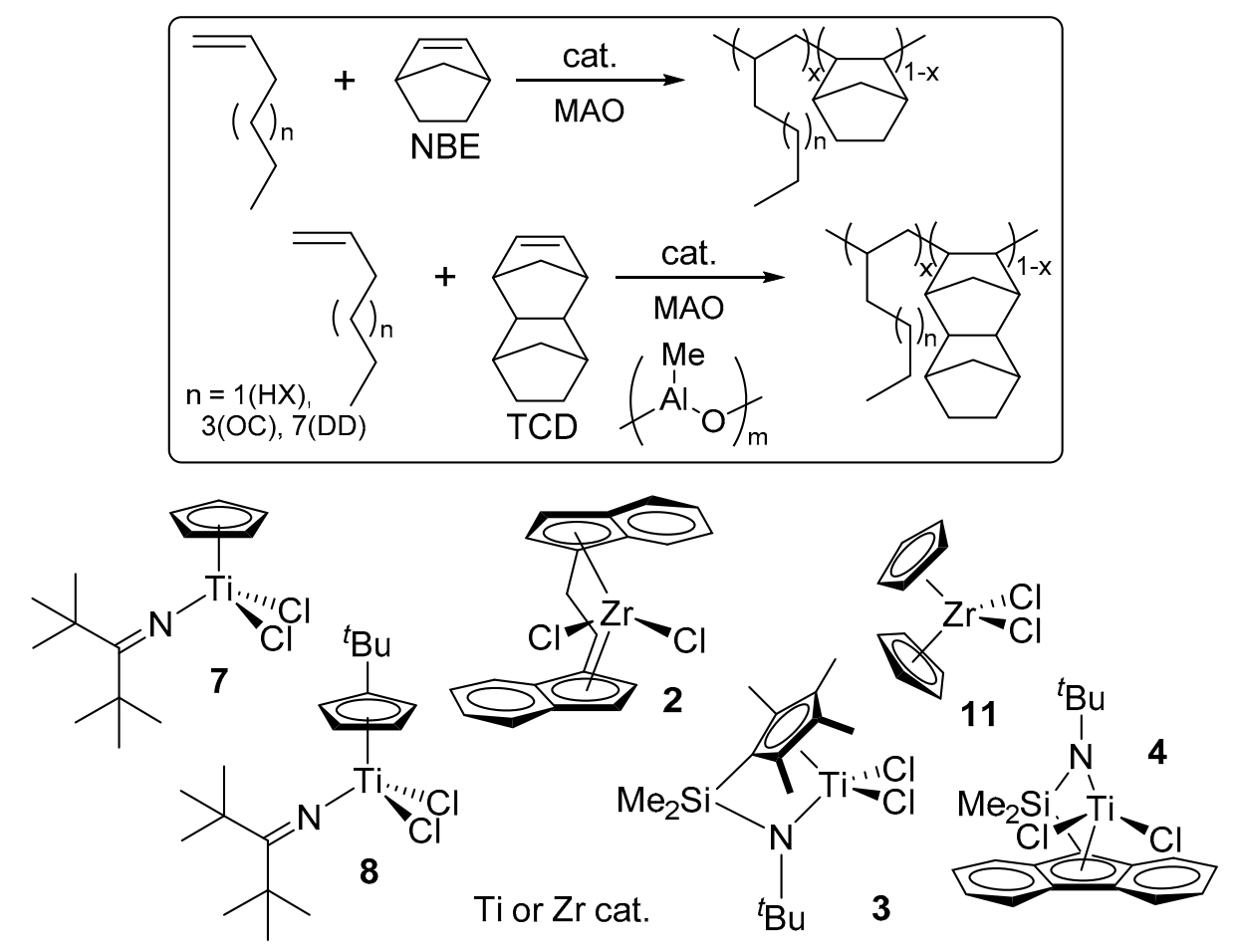

Scheme 4. Copolymerization of norbornene (NBE) and tetracyclododecene (TCD) with $\alpha$-olefin (1-hexene, 1-octene, and 1-dodecene) [54].

The copolymerization of TCD with HX by the Cp-ketimide analogue (7) afforded the copolymers with unimodal molecular weight distributions, with uniform compositions confirmed by DSC thermograms (Table 3) [54]. The copolymerizations with OC or DD by 7 afforded copolymers with high $T_{\mathrm{g}}$ values. In contrast, 8 showed low activity in the copolymerization with HX, OC, and DD. The attempted copolymerizations of TCD with $\mathrm{HX}$ by $\left[\mathrm{Me}_{2} \mathrm{Si}\left(\mathrm{C}_{5} \mathrm{Me}_{4}\right)\left(\mathrm{N}^{t} \mathrm{Bu}\right)\right] \mathrm{TiCl}_{2}$ (3)-MAO catalyst afforded a negligible amount of polymers in most cases; low molecular weight oligomer $\left(M_{n}=5300\right)$ with low TCD content (estimated by DSC thermogram, $T_{\mathrm{g}}=9.8^{\circ} \mathrm{C}$ ) was obtained under specified conditions. The copolymerizations with $\mathrm{HX}, \mathrm{OC}$, and $\mathrm{DD}$ by $\left[\mathrm{Et}\right.$ (indenyl) $\left.{ }_{2}\right] \mathrm{ZrCl}_{2}$ (2) or $\mathrm{Cp}_{2} \mathrm{ZrCl}_{2}$ (11) yielded a small amount of oligomer under certain conditions; this is in distinct contrast to that observed for $\mathrm{CpTiCl}_{2}\left(\mathrm{~N}={ }^{t} \mathrm{Bu}_{2}\right)(7)$. 
Table 3. Copolymerization of norbornene (NBE) or tetracyclododecene (TCD) with 1-hexene $(\mathrm{HX})$, 1-octene (OC), and 1-dodecene (DD) by $\left[\mathrm{Et}(\text { indenyl) })_{2}\right] \mathrm{ZrCl}_{2}$ (2), $\mathrm{Cp}_{2} \mathrm{ZrCl}_{2}$ (11), $\left[\mathrm{Me}_{2} \mathrm{Si}\left(\mathrm{C}_{5} \mathrm{Me}_{4}\right)\left(\mathrm{N}^{t} \mathrm{Bu}\right)\right] \mathrm{TiCl}_{2}(3), \mathrm{Cp}^{\prime} \mathrm{TiCl}_{2}\left(\mathrm{~N}=\mathrm{C}^{t} \mathrm{Bu}_{2}\right)\left(\mathrm{Cp}^{\prime}=\mathrm{Cp}(7),{ }^{t} \mathrm{BuC}_{5} \mathrm{H}_{4}(8)\right)-\mathrm{MAO}_{\text {catalysts. }}{ }^{a}$

\begin{tabular}{|c|c|c|c|c|c|c|c|c|c|c|}
\hline $\begin{array}{l}\text { Catalyst } \\
(\mu \mathrm{mol})\end{array}$ & $\begin{array}{l}\text { MAO/ } \\
\text { mmol }\end{array}$ & $\alpha$-olefin & $\mathrm{CO}$ & $\begin{array}{l}\text { CO Feed } \\
\text { ratio } b / \%\end{array}$ & $\begin{array}{l}\text { Time/ } \\
\text { min }\end{array}$ & Activity $^{c}$ & $M_{\mathrm{n}}^{\mathrm{d}} \times 10^{-4}$ & $M_{\mathrm{w}} / M_{\mathrm{n}}^{\mathrm{d}}$ & $\begin{array}{l}\text { CO cont. } \\
\text { e } / \mathrm{mol} \%\end{array}$ & $\begin{array}{l}T_{g} \mathrm{f} \\
\rho^{\circ} \mathrm{C}\end{array}$ \\
\hline $7(0.04)$ & 3.0 & HX & NBE & 12 & 30 & 7500 & 4.18 & 1.64 & 20.0 & 78 \\
\hline $7(0.04)$ & 3.0 & $\mathrm{HX}$ & NBE & 21 & 30 & 9620 & 3.61 & 1.58 & 37.2 & 126 \\
\hline $7(0.03)$ & 3.0 & HX & NBE & 44 & 60 & 12,900 & 4.09 & 1.72 & 64.5 & 211 \\
\hline $7(0.02)$ & 3.0 & HX & NBE & 57 & 60 & 12,500 & 3.94 & 1.61 & 69.2 & 246 \\
\hline $7(0.10)$ & 3.0 & OC & NBE & 14 & 60 & 6140 & 4.57 & 1.67 & 13.0 & 31 \\
\hline $7(0.05)$ & 3.0 & OC & NBE & 25 & 20 & 8240 & 3.33 & 1.63 & 39.6 & 99 \\
\hline $7(0.03)$ & 3.0 & OC & NBE & 50 & 60 & 7890 & 4.18 & 1.67 & 67.5 & 192 \\
\hline $7(0.03)$ & 3.0 & OC & NBE & 63 & 60 & 6220 & 4.79 & 3.24 & 77.6 & 235 \\
\hline $7(0.10)$ & 3.0 & DD & NBE & 32 & 60 & 4490 & 3.84 & 1.67 & 37.3 & 56 \\
\hline $7(0.03)$ & 3.0 & DD & NBE & 59 & 60 & 4580 & 5.42 & 1.75 & 76.1 & 157 \\
\hline $7(0.03)$ & 3.0 & DD & NBE & 70 & 60 & 4150 & 8.26 & 3.19 & 84.1 & 212 \\
\hline $8(0.20)$ & 3.0 & OC & NBE & 50 & 60 & 1720 & 6.49 & 1.69 & 37.0 & 102 \\
\hline $8(0.20)$ & 3.0 & OC & NBE & 63 & 60 & 930 & 6.34 & 1.68 & 49.2 & 135 \\
\hline $8(0.30)$ & 3.0 & DD & NBE & 59 & 60 & 1370 & 6.68 & 1.76 & 43.0 & 64 \\
\hline $8(0.20)$ & 3.0 & DD & NBE & 70 & 60 & 1650 & 6.61 & 1.64 & 55.0 & 100 \\
\hline $2(20)$ & 10 & HX & TCD & 75 & 10 & 49 & 0.73 & 1.18 & - & - \\
\hline $2(20)$ & 10 & OC & TCD & 75 & 20 & 26 & 0.76 & 1.22 & - & - \\
\hline $2(20)$ & 10 & DD & TCD & 75 & 20 & 21.5 & 0.71 & 1.25 & - & - \\
\hline $11(20)$ & 10 & HX & TCD & 75 & 120 & 1.0 & 1.4 & 1.27 & - & 98 \\
\hline $11(20)$ & 10 & OC & TCD & 75 & 120 & 0.9 & 1.5 & 1.28 & - & 83 \\
\hline $3(10)$ & 6.0 & HX & TCD & 50 & 30 & 31 & 5.3 & 1.41 & - & 9.8 \\
\hline $3(10)$ & 10 & OC & TCD & 75 & 60 & 6 & 3.6 & 1.37 & - & 6.3 \\
\hline $7(0.20)$ & 1.0 & $\mathrm{HX}$ & TCD & 50 & 15 & 4590 & 17.6 & 1.70 & 41.6 & 205 \\
\hline $7(0.20)$ & 1.5 & $\mathrm{HX}$ & TCD & 75 & 15 & 2870 & 12.2 & 1.76 & 62.8 & 271 \\
\hline $7(0.30)$ & 1.5 & OC & TCD & 75 & 15 & 2030 & 9.9 & 1.93 & 55.5 & 235 \\
\hline $7(0.40)$ & 1.0 & OC & TCD & 83 & 15 & 1410 & 1.03 & 1.74 & 67.6 & 259 \\
\hline $7(0.40)$ & 1.5 & DD & TCD & 75 & 15 & 1830 & 13.0 & 1.67 & 60.5 & 165 \\
\hline $8(0.50)$ & 1.0 & HX & TCD & 50 & 15 & 307 & - & - & - & - \\
\hline $8(0.60)$ & 1.5 & OC & TCD & 75 & 15 & 120 & - & - & - & - \\
\hline $8(1.0)$ & 1.5 & DD & TCD & 75 & 15 & 62 & - & - & - & - \\
\hline
\end{tabular}

${ }^{a}$ Conditions: toluene $1.0 \mathrm{~mL}, \mathrm{TCD} 2.0 \mathrm{~mL}(13.4 \mathrm{mmol}), 25^{\circ} \mathrm{C} ;{ }^{\mathrm{b}}$ cyclic olefin (CO: NBE, TCD) initial feed molar ratio; ${ }^{\mathrm{c}}$ activity $=\mathrm{kg}$-polymer $/ \mathrm{mol}-\mathrm{M} \cdot \mathrm{h} ;{ }^{\mathrm{d}}$ GPC data in tetrahydrofuran (THF) vs polystyrene stds; ${ }^{\mathrm{e}}$ estimated from ${ }^{13} \mathrm{C}$ NMR spectra; ${ }^{\mathrm{f}}$ Measured by differential scanning calorimetry (DSC) thermograms.

The activity in the TCD/HX copolymerization decreased upon increasing the TCD concentration, with increasing TCD content in the copolymer (Table 4) [54]. The resultant copolymers possessed rather high molecular weights with unimodal molecular weight distributions $\left(M_{n}=12,000-27,600\right.$, $M_{\mathrm{W}} / M_{n}=1.20-1.76$ ), and the TCD content (estimated by ${ }^{13} \mathrm{C}$ NMR spectra) increased upon increasing TCD concentration with an increasing glass transition temperature $\left(T_{\mathrm{g}}\right)$; synthesis of the copolymers with high $T_{\mathrm{g}}$ (e.g., $286{ }^{\circ} \mathrm{C}$ ) could be thus attained by adopting this catalysis. The activity was also affected by MAO (Al/Ti molar ratio), especially under high TCD concentration conditions, and no significant differences in either the molecular weights or $T_{\mathrm{g}}$ values of the copolymers were observed. Similarly, the copolymerizations of TCD with OC or DD afforded copolymers possessing rather high molecular weights with unimodal molecular weight distributions $\left(M_{n}=9900-25,600\right.$, $\left.M_{\mathrm{W}} / M_{n}=1.61-1.93\right)$; the TCD content increased upon increasing TCD concentration with an increase in the $T_{\mathrm{g}}$ values. Moreover, the TCD incorporation by the 7-MAO catalyst was not strongly affected by the nature of the $\alpha$-olefin employed (HX, OC, or DD) under high TCD/ $\alpha$-olefin feed conditions; relatively linear correlations were observed between TCD content in the copolymers and TCD/ $\alpha$-olefin feed molar ratios. 

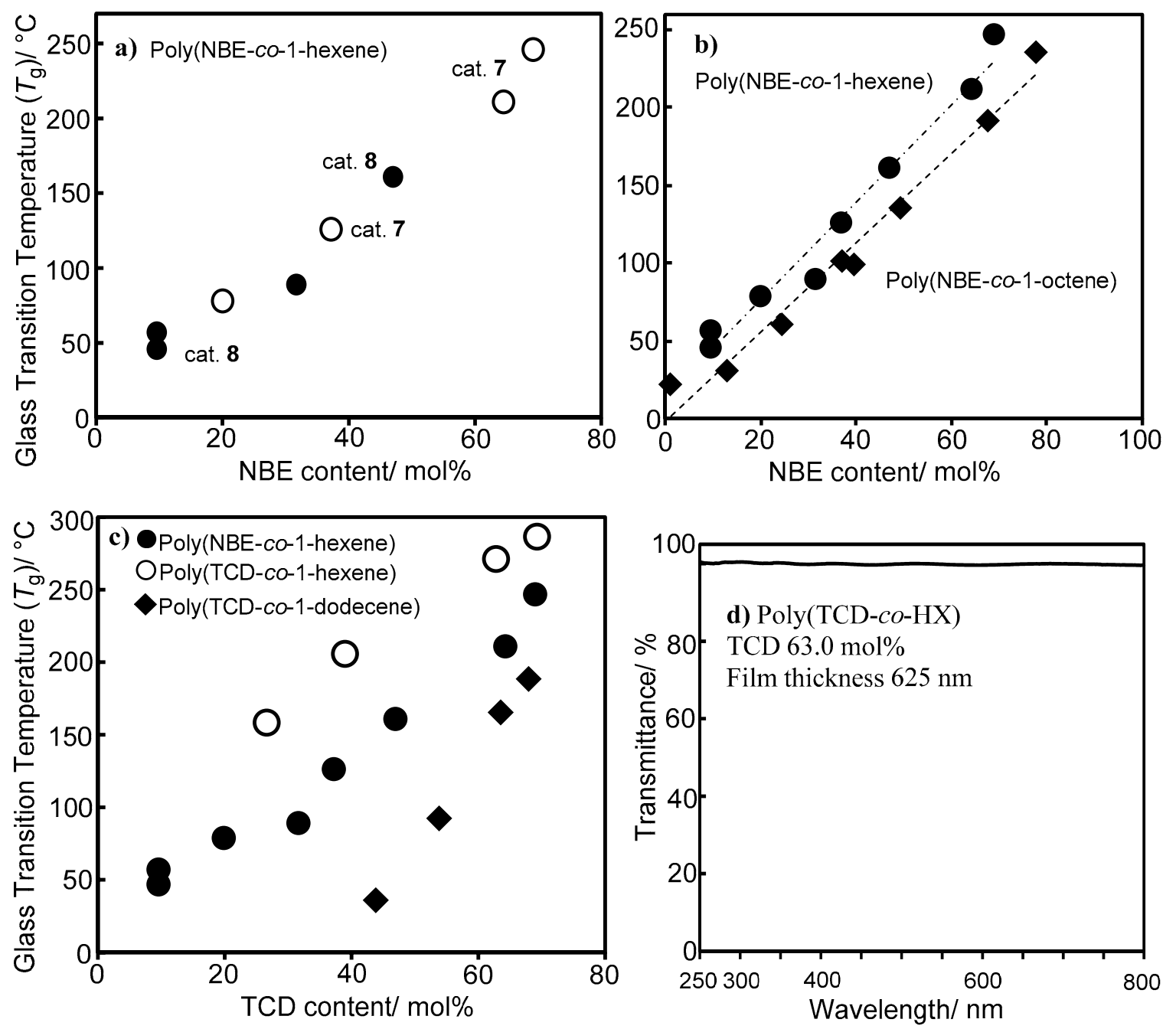

Figure 1. Plots of glass transition temperature $\left(T_{\mathrm{g}}\right)$ vs NBE content (mol \%) in (a) poly(NBE-co-1-hexene)s by $\mathrm{Cp}^{\prime} \mathrm{TiCl}_{2}\left(\mathrm{~N}=\mathrm{C}^{t} \mathrm{Bu}_{2}\right)\left(\mathrm{Cp}^{\prime}=\mathrm{Cp}(\mathbf{7}, \bigcirc)\right.$ or $\left.{ }^{t} \mathrm{BuC}_{5} \mathrm{H}_{4}(\mathbf{8}, \bullet)\right)-\mathrm{MAO}$ catalysts; (b) poly(NBE-co-1-hexene)s (marked with $\bullet$ ) and poly(NBE-co-1-octene)s (marked with $)$; (c) plots of $T_{\mathrm{g}}$ values vs TCD content (mol \%) in poly(TCD-co-1-hexene)s and poly(TCD-co-1-dodecene)s; (d) plots of transmittance vs wavelength in poly(TCD-co-1-hexene) [54].

Table 4. Copolymerization of tetracyclododecene (TCD) with 1-hexene (HX), 1-octene (OC), or 1-dodecene (DD) by $\mathrm{CpTiCl}_{2}\left(\mathrm{~N}=\mathrm{C}^{t} \mathrm{Bu}_{2}\right)(7)-\mathrm{MAO}$ catalyst ${ }^{\mathrm{a}}$.

\begin{tabular}{|c|c|c|c|c|c|c|c|c|c|}
\hline $\begin{array}{l}\text { Catalyst } \\
\text { ( } \mu \mathrm{mol})\end{array}$ & $\begin{array}{l}\text { MAO/ } \\
\text { mmol }\end{array}$ & $\alpha$-olefin & $\begin{array}{l}\text { TCD Feed } \\
\text { Ratio } / \%\end{array}$ & temp. $/{ }^{\circ} \mathrm{C}$ & Activity $^{c}$ & $M_{\mathrm{n}}^{\mathrm{d}} \times 10^{-4}$ & $M_{\mathrm{w}} / M_{\mathrm{n}}^{\mathrm{d}}$ & $\begin{array}{l}\text { TCD cont. } \\
\mathrm{e} / \mathrm{mol} \%\end{array}$ & $T_{g}{ }^{\mathrm{f}} /{ }^{\circ} \mathrm{C}$ \\
\hline $7(0.20)$ & 1.0 & HX & 50 & 25 & 4590 & 17.6 & 1.70 & 41.6 & 205 \\
\hline $7(0.20)$ & 1.0 & HX & 75 & 25 & 2560 & 1.42 & 1.66 & - & - \\
\hline $7(0.20)$ & 1.5 & HX & 75 & 25 & 2870 & 12.2 & 1.76 & 62.8 & 271 \\
\hline $7(0.20)$ & 1.5 & HX & 75 & 50 & 2550 & 1.18 & 1.73 & - & 282 \\
\hline $7(0.20)$ & 1.5 & HX & 75 & 70 & 1670 & 1.01 & 1.71 & - & 289 \\
\hline $7(0.20)$ & 1.0 & OC & 50 & 25 & 4210 & 1.83 & 1.61 & 44.4 & 172 \\
\hline $7(0.30)$ & 1.5 & OC & 75 & 25 & 2030 & 9.9 & 1.93 & 55.5 & 235 \\
\hline $7(0.40)$ & 1.0 & $\mathrm{OC}$ & 83 & 25 & 1410 & 1.03 & 1.74 & 67.6 & 259 \\
\hline $7(0.40)$ & 1.5 & DD & 75 & 25 & 1830 & 13.0 & 1.67 & 60.5 & 165 \\
\hline
\end{tabular}

a Conditions: toluene $1.0 \mathrm{~mL}$, TCD $2.0 \mathrm{~mL}(13.4 \mathrm{mmol}), 15 \mathrm{~min} ;{ }^{\mathrm{b}}$ TCD initial feed molar ratio; ${ }^{c}$ activity $=\mathrm{kg}$-polymer $/ \mathrm{mol}-\mathrm{M} \cdot \mathrm{h} ;{ }^{\mathrm{d}}$ GPC data in THF vs polystyrene stds; ${ }^{\mathrm{e}}$ estimated from ${ }^{13} \mathrm{C}$ NMR spectra;

${ }^{\mathrm{f}}$ measured by DSC thermogram. 
Fairly good linear relationships between the $T_{\mathrm{g}}$ values and the TCD content in poly(TCD-co-HX)s, poly(TCD-co-OC)s, and poly(TCD-co-DD)s were observed (Figure 1c), and the $T_{\mathrm{g}}$ values in the resultant copolymers are affected by the $\alpha$-olefin employed. It is clear that the $T_{\mathrm{g}}$ values in poly(TCD-co-HX)s, [poly(TCD-co-OC)s, and poly(TCD-co-DD)s] are higher than those in poly(NBE-co-HX)s [poly(NBE-co-OC)s, and poly(NBE-co-DD)s] with the same $\alpha$-olefin content (Figure 1c). Synthesis of high molecular weight copolymers of (long chain) $\alpha$-olefins with various TCD content (with uniform molecular weight distributions and compositions) can be achieved by using these catalysts. Moreover, the resultant copolymers, poly(TCD-co-HX)s and poly(TCD-co-OC)s, show high transparency as thin films (Figure 1d), demonstrating a possibility that these polymers are promising materials with high transparency as well as with high glass transition temperatures $\left(T_{\mathrm{g}}>230^{\circ} \mathrm{C}\right)$.

\section{Efficient Norbornene (NBE) Incorporation in Ethylene/NBE Copolymerization by Half-Titanocene Catalysts Containing Chlorinated Aryloxo Ligands}

As shown in Table 5, the $\mathrm{Cp}$-chlorinated phenoxy analogues, $\mathrm{CpTiCl}_{2}(\mathrm{OAr})\left(\mathrm{Ar}=2,6-\mathrm{Cl}_{2} \mathrm{C}_{6} \mathrm{H}_{3}(\mathbf{1 2})\right.$, 2,4,6- $\mathrm{Cl}_{3} \mathrm{C}_{6} \mathrm{H}_{2}$ (13), or $\left.\mathrm{C}_{6} \mathrm{Cl}_{5}(\mathbf{1 4})\right)$, showed higher catalytic activity (2010-3090 kg-polymer/mol-Ti-h) than the reported (Ind) $\mathrm{TiCl}_{2}\left(\mathrm{O}-2,6-{ }^{i} \mathrm{Pr}_{2} \mathrm{C}_{6} \mathrm{H}_{3}\right)$ (6) and $\mathrm{CpTiCl}_{2}\left(\mathrm{O}-2,6-{ }^{i} \mathrm{Pr}_{2} \mathrm{C}_{6} \mathrm{H}_{3}\right)($ (15) under the same conditions in the presence of the MAO cocatalyst (Scheme 5) [70]. The activities of 12-14 were also higher than those of the indenyl analogues. The resultant polymers are poly(ethylene-co-NBE)s possessing rather high molecular weights $\left(M_{n}=45,400-82,500\right)$ with uniform molecular weight distributions $\left(M_{\mathrm{w}} / M_{n}=1.29-1.63\right)$, and their compositions are uniform, as confirmed by DSC thermograms. These are similar observations to those of copolymerization by the 6-MAO catalyst, but the resultant polymer prepared by $\mathbf{1 5}$ possessed bimodal molecular weight distributions, as previously observed in ethylene/1-hexene copolymerization [71], suggesting that several catalytically active species are present in the solution.

Table 5. Copolymerization of ethylene with norbornene (NBE) by $\mathrm{Cp}^{\prime} \mathrm{TiCl}_{2}(\mathrm{OAr})\left(\mathrm{Cp}^{\prime}=\mathrm{Cp}\right.$, $\mathrm{Ar}=2,6-\mathrm{Cl}_{2} \mathrm{C}_{6} \mathrm{H}_{3}$ (12), 2,4,6- $-\mathrm{Cl}_{3} \mathrm{C}_{6} \mathrm{H}_{2}$ (13), $\mathrm{C}_{6} \mathrm{Cl}_{5}$ (14), or 2,6- ${ }^{i} \mathrm{Pr}_{2} \mathrm{C}_{6} \mathrm{H}_{3}$ (15); $\mathrm{Cp}^{\prime}=$ indenyl, $\left.\mathrm{Ar}=2,6-{ }^{i} \mathrm{Pr}_{2} \mathrm{C}_{6} \mathrm{H}_{3}(6)\right)-\mathrm{MAO}$ catalysts ${ }^{\mathrm{a}}$.

\begin{tabular}{|c|c|c|c|c|c|c|c|}
\hline Cat. ( $\mu \mathrm{mol})$ & $\begin{array}{c}\text { NBE } \\
\text { Feed/mol/L }\end{array}$ & Temp. $/{ }^{\circ} \mathrm{C}$ & Activity ${ }^{b}$ & $T_{\mathrm{g}}{ }^{\mathrm{c}} /{ }^{\circ} \mathrm{C}$ & $M_{\mathrm{n}}^{\mathrm{d}} \times 10^{-4}$ & $M_{\mathrm{w}} / M_{\mathrm{n}}^{\mathrm{d}}$ & $\begin{array}{l}\text { NBE cont. } \\
\mathrm{e} / \mathrm{mol} \%\end{array}$ \\
\hline $12(0.3)$ & 1.0 & 25 & 2470 & 153 & 5.47 & 1.55 & 49.6 \\
\hline $12(0.5)$ & 2.0 & 40 & 2390 & 176 & 5.60 & 1.56 & - \\
\hline $13(0.3)$ & 1.0 & 25 & 3090 & 142 & 7.41 & 1.50 & 45.3 \\
\hline $13(0.3)$ & 1.0 & 40 & 4140 & 151 & 6.50 & 1.37 & - \\
\hline $13(0.5)^{f}$ & 2.0 & 25 & 3060 & 156 & 8.25 & 1.37 & 53.3 \\
\hline $13(0.3)$ & 2.0 & 50 & 2350 & 176 & 3.50 & 1.65 & 58.8 \\
\hline $14(0.3)$ & 1.0 & 25 & 2320 & 128 & 6.01 & 1.49 & 42.3 \\
\hline $14(0.6)^{f}$ & 2.0 & 25 & 2030 & 150 & 6.94 & 1.40 & - \\
\hline $15(2.5)$ & 2.0 & 25 & 319 & - & \multicolumn{2}{|c|}{ bimodal } & - \\
\hline $6(2.0)$ & 2.0 & 25 & 492 & 114 & 2.52 & 1.29 & - \\
\hline
\end{tabular}

${ }^{\text {a }}$ Conditions: toluene + NBE total $50 \mathrm{~mL}$, MAO white solid (prepared by removing $\mathrm{AlMe}_{3}$, toluene from TMAO, MAO: methylaluminoxane) $3.0 \mathrm{mmol}$, ethylene $4 \mathrm{~atm}, 25^{\circ} \mathrm{C} ;{ }^{\text {b }}$ activity in $\mathrm{kg}$-polymer $/ \mathrm{mol}-\mathrm{Ti} \cdot \mathrm{h} ;{ }^{\mathrm{c}}$ glass transition temperature $\left(T_{\mathrm{g}}\right)$ measured by DSC; ${ }^{\mathrm{d}}$ GPC data in $o$-dichlorobenzene vs polystyrene standards; ${ }^{\mathrm{e}} \mathrm{NBE}$ content estimated by ${ }^{13} \mathrm{C}$ NMR spectra; ${ }^{\mathrm{f}}$ time $6 \mathrm{~min}$. $\mathrm{CpTiCl}_{2}\left(\mathrm{~N}=\mathrm{C}^{t} \mathrm{Bu}_{2}\right)(7)$, CGC: $\left[\mathrm{Me}_{2} \mathrm{Si}_{(}\left(\mathrm{C}_{5} \mathrm{Me}_{4}\right)\left(\mathrm{N}^{t} \mathrm{Bu}\right)\right] \mathrm{TiCl}_{2}$ (3); DSBI: $\left[\mathrm{Me}_{2} \mathrm{Si}(\text { indenyl) })_{2}\right] \mathrm{ZrCl}_{2}$ (1). 


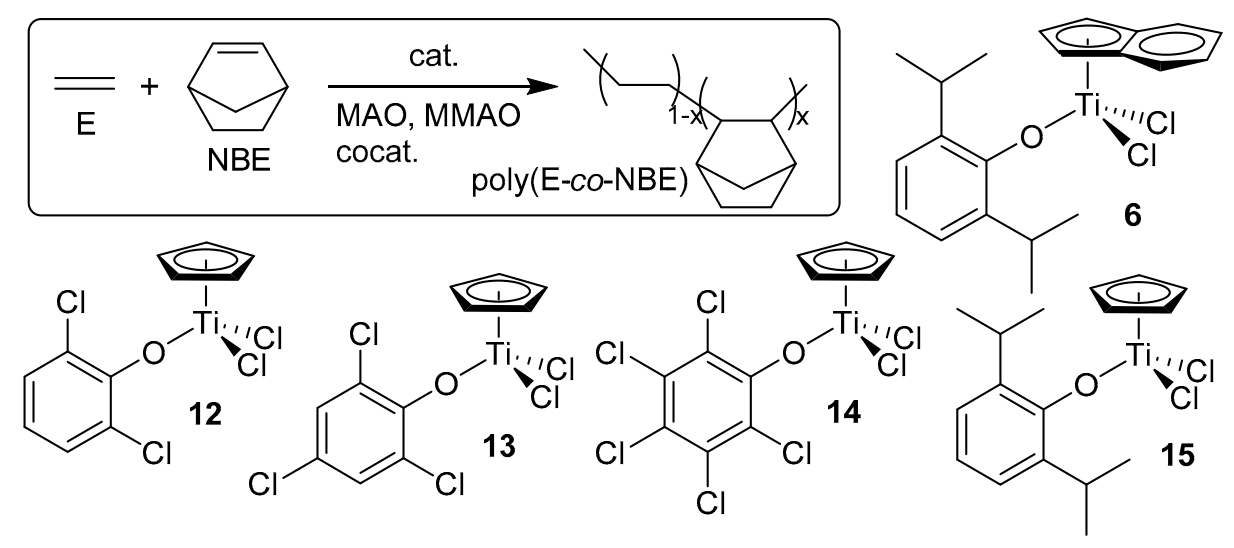

Scheme 5. Copolymerization of ethylene with norbornene with half-titanocenes containing chlorinated aryloxo ligands [70].

Note that the NBE content in the resultant copolymers (estimated by glass transition temperature $\left.\left(T_{\mathrm{g}}\right)\right)$ prepared by 12-14 are higher than those prepared by the others under the same conditions; the NBE content by 12 and 13 (NBE content 49.6 and $45.3 \mathrm{~mol} \%$, respectively) is much higher than $\left[\mathrm{Me}_{2} \mathrm{Si}\left(\mathrm{C}_{5} \mathrm{Me}_{4}\right)\left(\mathrm{N}^{t} \mathrm{Bu}\right)\right] \mathrm{TiCl}_{2}(\mathrm{CGC}, 3,29.5 \mathrm{~mol} \%)$, [ $\mathrm{Me}_{2} \mathrm{Si}$ (indenyl) $\left.{ }_{2}\right] \mathrm{ZrCl}_{2}$ (DSBI, 1, $26.5 \mathrm{~mol} \%$ ), and $\mathrm{CpTiCl}_{2}\left(\mathrm{~N}=\mathrm{C}^{t} \mathrm{Bu}_{2}\right)(7)$ under the same conditions. Although the activities of $\mathbf{1 2}$ and $\mathbf{1 3}$ were lower than that of 7 (but at a higher or similar level compared to CGC and DSBI), the results thus clearly indicate that the chlorinated phenoxy-modified $\mathrm{Cp}$ analogues, especially 12 and 13, showed the most efficient NBE incorporation compared with the others under these conditions. The 2,4,6- $\mathrm{Cl}_{3} \mathrm{C}_{6} \mathrm{H}_{2}$ analogue (13) showed higher catalytic activity than that of the 2,6- $\mathrm{Cl}_{2} \mathrm{C}_{6} \mathrm{H}_{3}$ analogue (12), whereas 12 showed better NBE incorporation than 13 under the same conditions (e.g., run 1 vs run 4). The activity (on the basis of polymer yields) of 13 at $40-60{ }^{\circ} \mathrm{C}$ was higher than that conducted at $25^{\circ} \mathrm{C}$; the activity of $\mathbf{1 2}$ at $40{ }^{\circ} \mathrm{C}$ was higher than that conducted at $25^{\circ} \mathrm{C}$. A linear relationship between the NBE content in the resultant copolymers and glass transition temperature $\left(T_{\mathrm{g}}\right)$ was observed.

As far as we know, this is the first demonstration that an introduction of electron-withdrawing substituents leads to more efficient comonomer incorporation in ethylene/cyclic olefin copolymerization. This fact would be in distinct contrast to the catalyst design in ordinary olefin (ethylene and styrene) polymerization, in which stabilization of the active site by more electron-donating substituents is important, leading to the high activity. The results from this study demonstrate a possibility that control of $\pi$-donation (which would affect the ability of accepting $\pi$-electrons from olefins) plays a role for the efficient incorporation of (sterically encumbered) cyclic olefins in this catalysis.

\section{Summary and Outlook}

We have shown that efficient incorporations of norbornene (NBE) and tetracyclododenece (TCD) have been achieved in the copolymerization with ethylene, 1-hexene (HX), 1-octene (OC), and with 1-dodecene (DD) by using $\mathrm{Cp}^{\prime} \mathrm{TiCl} 2(\mathrm{~N}=\mathrm{CtBu} 2)\left(\mathrm{Cp}^{\prime}=\mathrm{Cp}(7), \mathrm{tBuC} 5 \mathrm{H} 4(8)\right)-\mathrm{MAO}$ catalysts. The resultant copolymers possess rather high molecular weights, unimodal molecular weight distributions, and uniform compositions as confirmed by DSC thermograms. This is, as far as we know, the first demonstration for the synthesis of TCD/ $\alpha$-olefin copolymers, in addition to preparation of a series of random poly(NBE-co- $\alpha$-olefin)s with various NBE content. Moreover, the efficient synthesis of poly(ethylene-co-TCD)s has also been attained in this catalysis. These copolymers possess a high glass transition temperature (thermal resistance) with high transparency and should show unique properties (e.g., humidity resistance). It is thus highly expected that these polymers are promising materials as a new class of cyclic olefin copolymers (COCs). 
As described in the introduction, design of molecular catalysts that precisely control the copolymerization has attracted considerable attention for the synthesis of new polymers with specified functions. The ligand design plays an essential role, and we demonstrated in so-called nonbridged half-titanocene catalysts $-\mathrm{Cp}^{\prime} \mathrm{TiX}_{2}(Y)\left(\mathrm{Cp}^{\prime}=\right.$ cyclopentadienyl; $X=$ halogen, alkyl etc.; $Y=$ anionic ancillary donor such as aryloxy, ketimide, imidazolin-2-iminato, etc.)-that efficient catalysts for the desired copolymerization can be tuned by the ligand modification on both the cyclopentadienyl fragment and nature (and substituents) of the anionic donor ligand employed, as demonstrated in the ethylene copolymerization with NBE [22-24], TCD [53], cyclohexene [72], cyclopentene [73], 2-methyl-1-pentene [74], and the others [39,41,45], as summarized in Scheme 6. We thus believe that the results demonstrated here are promising in terms of the synthesis of new polymers, and provides a better understanding not only for the polymer design (combination of monomers), but also for the catalyst design for efficient synthesis.

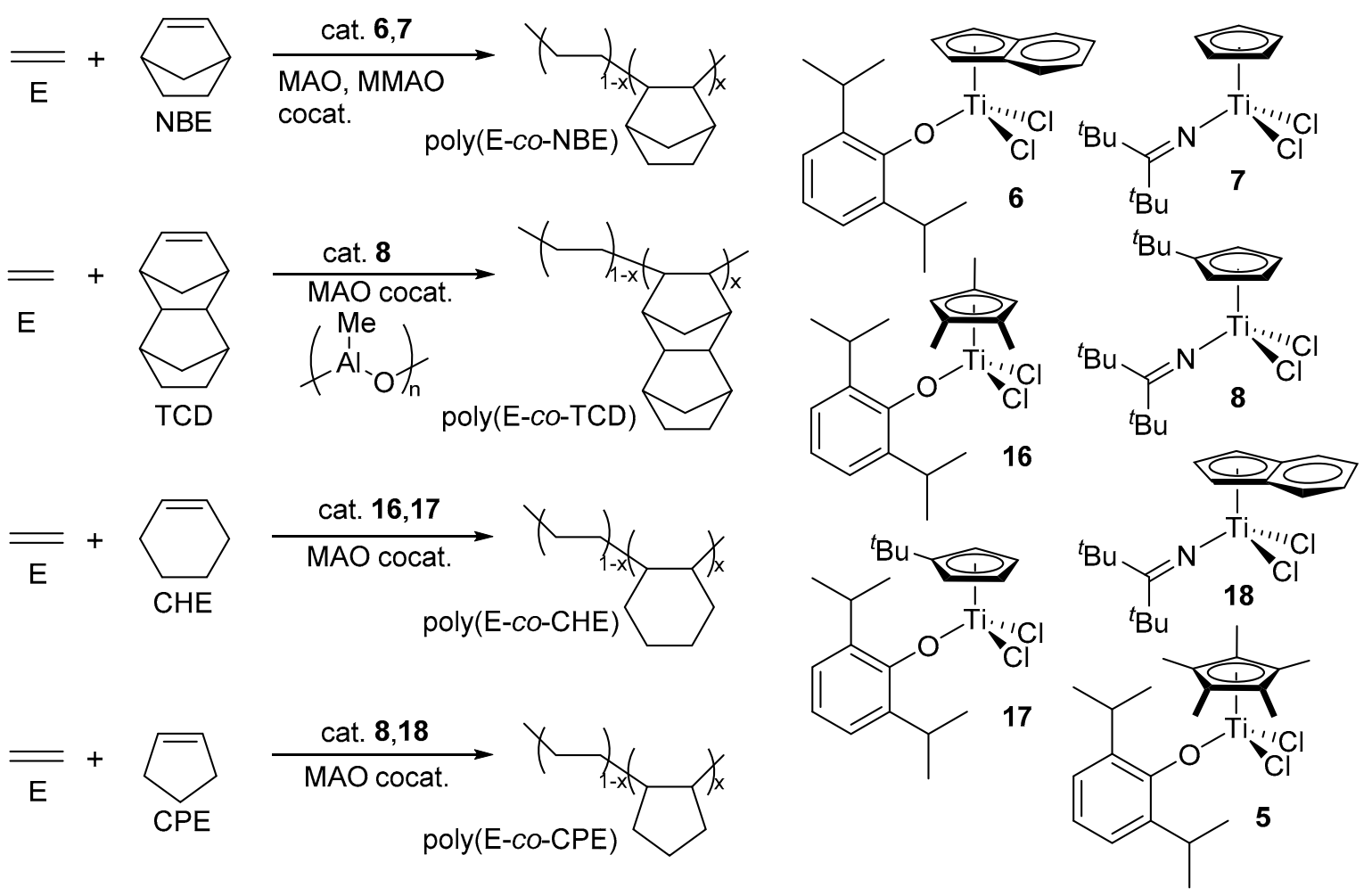

Scheme 6. Ethylene copolymerization with cyclic olefins by modified half-titanocene catalysts [22-24,39,41,45,53,72-74].

Acknowledgments: K.N. expresses his heartfelt thanks to former/present group members who contributed this project as coauthors, and the other members for discussion/supports. The present research is partly supported by Grant-in-Aid for Scientific Research (B) from the Japan Society for the Promotion of Science (JSPS, No. 18350055, 21350054, 24350049, 15H03812). W.Z. expresses her thanks to Tokyo metropolitan government (Asian Human Resources Fund) for pre-doctoral fellowship, and the project was partly supported by the advanced research program (Tokyo metropolitan government). The authors also express their thanks to Tosoh Finechem Co. for donating MAO (TMAO) and Zeon Corp. for donating tetracycylododecene (TCD) sample.

Author Contributions: W.Z. wrote the initial draft and K.N. revised for submission. Some experiments cited as references were conducted by W.Z. Authorship must be limited to those who have contributed substantially to the work reported.

Conflicts of Interest: The authors declare no competing financial interest. 


\section{References and Notes}

1. Kaminsky, W. Olefinpolymerisation mittels metallocenkatalysatoren. Angew. Makromol. Chem. 1994, 223, 101-120. [CrossRef]

2. Cherdron, H.; Brekner, M.-J.; Osan, F. Cycloolefin copolymer: A new class of transparent thermoplastics. Angew. Makromol. Chem. 1994, 223, 121-133. [CrossRef]

3. Kaminsky, W.; Beulich, I.; Arndt-Rosenau, M. Copolymerization of ethene with cyclic and other sterically hindered olefins. Macromol. Symp. 2001, 173, 211-226. [CrossRef]

4. Dragutan, V.; Streck, R. Catalytic Polymerisation of Cycloolefins-Ionic, Ziegler-Natta and Ring-Opening Metathesis Polymerization. In Studies in Surface Science and Catalysis; Elsevier: Amsterdam, The Netherlands, 2000; Volume 131.

5. Tritto, I.; Boggioni, L.; Ferro, D.R. Metallocene catalyzed ethene- and propene co-norbornene polymerization: Mechanisms from a detailed microstructural analysis. Coord. Chem. Rev. 2006, 250, 212-241. [CrossRef]

6. Nomura, K. Nonbridged half-titanocenes containing anionic ancillary donor ligands: Promising new catalysts for precise synthesis of cyclic olefin copolymers (COCs). Chin. J. Polym. Sci. 2008, 26, 513-523. [CrossRef]

7. Li, X.; Hou, Z. Organometallic catalysts for copolymerization of cyclic olefins. Coord. Chem. Rev. 2008, 252, 1842-1869. [CrossRef]

8. TOPAS. Available online: http://www.topas.com/products/topas-coc-polymers (accessed on 31 October 2016).

9. APEL. Available online: http://www.mitsuichem.com/service/functional_polymeric/polymers/apel/ (accessed on 31 October 2016).

10. Ruchatz, D.; Fink, G. Ethene-Norbornene copolymerization using homogenous metallocene and half-sandwich catalysts: Kinetics and relationships between catalyst structure and polymer structure. 1. Kinetics of the ethane-norbornene copolymerization using the [(isopropylidene) ( $\eta^{5}$-inden-1-ylidene- $\eta^{5}$-cyclopentadienyl)]zirconium dichloride/methylaluminoxane catalyst. Macromolecules 1998, 31, 4669-4673. [PubMed]

11. Ruchatz, D.; Fink, G. Ethene-Norbornene copolymerization using homogenous metallocene and half-sandwich catalysts: Kinetics and relationships between catalyst structure and polymer structure. 2. Comparative study of different metallocene- and half-sandwich/methylaluminoxane catalysts and analysis of the copolymers by ${ }^{13} \mathrm{C}$ nuclear magnetic resonance spectroscopy. Macromolecules 1998, 31, 4674-4680. [PubMed]

12. Ruchatz, D.; Fink, G. Ethene-Norbornene copolymerization with homogeneous metallocene and half-sandwich catalysts: Kinetics and relationships between catalyst structure and polymer structure. 3. Copolymerization parameters and copolymerization diagrams. Macromolecules 1998, 31, 4681-4683. [CrossRef] [PubMed]

13. Ruchatz, D.; Fink, G. Ethene-Norbornene copolymerization with homogeneous metallocene and half-sandwich catalysts: Kinetics and relationships between catalyst structure and polymer structure. 4 . Development of molecular weights. Macromolecules 1998, 31, 4684-4686. [CrossRef] [PubMed]

14. Provasoli, A.; Ferro, D.R.; Tritto, I.; Boggioni, L. The conformational characteristics of ethylene-norbornene copolymers and their influence on the ${ }^{13} \mathrm{C}$ NMR spectra. Macromolecules 1999, 32, 6697-6706. [CrossRef]

15. Tritto, I.; Marestin, C.; Boggioni, L.; Zetta, L.; Provasoli, A.; Ferro, D.R. Ethylene-Norbornene copolymer microstructure. Assessment and advances based on assignments of ${ }^{13} \mathrm{C}$ NMR spectra. Macromolecules 2000, 33, 8931-8944. [CrossRef]

16. Tritto, I.; Marestin, C.; Boggioni, L.; Sacchi, M.C.; Brintzinger, H.-H.; Ferro, D.R. Stereoregular and stereoirregular alternating ethylene-norbornene copolymers. Macromolecules 2001, 34, 5770-5777. [CrossRef]

17. Tritto, I.; Boggioni, L.; Jansen, J.C.; Thorshaug, K.; Sacchi, M.C.; Ferro, D.R. Ethylene-Norbornene copolymers from metallocene-based catalysts: Microstructure at tetrad level and reactivity ratios. Macromolecules 2002, 35, 616-623. [CrossRef]

18. Harrington, B.A.; Crowther, D.J. Stereoregular, alternating ethylene-norbornene copolymers from monocyclopentadienyl catalysts activated with non-coordinating discrete anions. J. Mol. Catal. A: Chem. 1998, 128, 79-84. [CrossRef] 
19. McKnight, A.L.; Waymouth, R.M. Ethylene/Norbornene copolymerizations with titanium CpA catalysts. Macromolecules 1999, 32, 2816-2825. [CrossRef]

20. Thorshaug, K.; Mendichi, R.; Boggioni, L.; Tritto, I.; Trinkle, S.; Friedrich, C.; Mülhaupt, R. Poly(ethene-co-norbornene) obtained with a constrained geometry catalyst. A study of reaction kinetics and copolymer properties. Macromolecules 2002, 35, 2903-2911. [CrossRef]

21. Hasan, T.; Ikeda, T.; Shiono, T. Ethene-Norbornene copolymer with high norbornene content produced by ansa-fluorenylamidodimethyltitanium complex using a suitable activator. Macromolecules 2004, 37, 8503-8509. [CrossRef]

22. Nomura, K.; Tsubota, M.; Fujiki, M. Efficient ethylene/norbornene copolymerization by (aryloxo)(indenyl)titanium(IV) complexes-MAO catalyst system. Macromolecules 2003, 36, 3797-3799. [CrossRef]

23. Wang, W.; Tanaka, T.; Tsubota, M.; Fujiki, M.; Yamanaka, S.; Nomura, K. Effect of cyclopentadienyl fragment in copolymerization of ethylene with cyclic olefins catalyzed by non-bridged (aryloxo)(cyclopentadienyl)titanium(IV) complexes. Adv. Synth. Catal. 2005, 347, 433-446. [CrossRef]

24. Nomura, K.; Wang, W.; Fujiki, M.; Liu, J. Notable norbornene (NBE) incorporation in ethylene-NBE copolymerization catalysed by nonbridged half-titanocenes: Better correlation between NBE incorporation and coordination energy. Chem. Commun. 2006, 2659-2661. [CrossRef] [PubMed]

25. Nomura, K.; Fukuda, H.; Katao, S.; Fujiki, M.; Kim, H.J.; Kim, D.H.; Saeed, I. Olefin polymerization by half-titanocenes containing $\eta^{2}$-pyrazolato ligands-MAO catalyst systems. Macromolecules 2011, 44, 1986-1998. [CrossRef]

26. Apisuk, W.; Trambitas, A.G.; Kitiyanan, B.; Tamm, M.; Nomura, K. Efficient ethylene/norbornene copolymerization by half-titanocenes containing imidazolin-2-iminato ligands and MAO catalyst systems. J. Polym. Sci. Part A: Polym. Chem. 2013, 51, 2575-2580. [CrossRef]

27. Altamura, P.; Grassi, A. Crystalline alternating sequences identified in ethylene-co-norbornene polymers produced by the $\left(\eta^{5}-\mathrm{C}_{2} \mathrm{~B}_{9} \mathrm{H}_{11}\right) \mathrm{Zr}\left(\mathrm{NEt}_{2}\right)_{2}\left(\mathrm{NHEt}_{2}\right)-\mathrm{Al}^{i} \mathrm{Bu}_{3}$ catalyst. Macromolecules 2001, 34, 9197-9200. [CrossRef]

28. Yoshida, Y.; Saito, J.; Mitani, M.; Takagi, Y.; Matsui, S.; Ishii, S.; Nakano, T.; Kashiwa, N.; Fujita, T. Living ethylene/norbornene copolymerisation catalyzed by titanium complexes having two pyrrolide-imine chelate ligands. Chem. Commun. 2002, 12, 1298-1299. [CrossRef]

29. Yoshida, Y.; Mohri, J.; Ishii, S.; Mitani, M.; Saito, J.; Matsui, S.; Makio, H.; Nakano, T.; Tanaka, H.; Onda, M.; et al. Living copolymerization of ethylene with norbornene catalyzed by bis(pyrrolide-imine) titanium complexes with MAO. J. Am. Chem. Soc. 2004, 126, 12023-12032. [CrossRef] [PubMed]

30. Li, X.-F.; Dai, K.; Ye, W.-P.; Pan, L.; Li, Y.-S. New titanium complexes with two $\beta$-enaminoketonato chelate ligands: Syntheses, structures, and olefin polymerization activities. Organometallics 2004, 23, 1223-1230. [CrossRef]

31. For example, synthesis of poly(ethylene-co-TCD)s using vanadium catalyst systems $\left[\mathrm{VOCl}_{3}\right.$, $\mathrm{VO}(\mathrm{OEt}) \mathrm{Cl}_{2}-\mathrm{EtAlCl}_{2} \cdot \mathrm{Et}_{2} \mathrm{AlCl}$ etc.] in the presence of halogenated Al cocatalyst, JP2001-106730; JP2006-22266; JP2008-248171 (Mitsui Chemicals Co.).

32. Kaminsky, W.; Bark, A. Copolymerization of ethene and dimethanooctahydronaphthalene with aluminoxane containing catalysts. Polym. Int. 1992, 28, 251-253. [CrossRef]

33. Kaminsky, W.; Engehausen, R.; Kopf, J. A tailor-made metallocene for the copolymerization of ethene with bulky cycloalkenes. Angew. Chem. Int. Ed. Engl. 1995, 34, 2273-2275. [CrossRef]

34. Goodall, B.L.; McIntosh, L.H.; Rhodes, L.F. New catalysts for the polymerization of cyclic olefins. Macromol. Symp. 1995, 89, 421-432. [CrossRef]

35. Donner, M.; Fernandes, M.; Kaminsky, W. Synthesis of copolymers with sterically hindered and polar monomers. Macromol. Symp. 2006, 236, 193-202. [CrossRef]

36. JP2006-307194 (Sumitomo Chemical Co., Ltd.); JP 2015-199919 (Mitsui Chemicals Co.).

37. Gibson, V.C.; Spitzmesser, S.K. Advances in non-metallocene olefin polymerization catalysis. Chem. Rev. 2003, 103, 283-316. [CrossRef] [PubMed]

38. Mason, A.F.; Coates, G.W. Macromolecular Engineering; Matyjaszewski, K., Gnanou, Y., Leibler, L., Eds.; Wiley-VCH: Weinheim, Germany, 2007; Volume 1, pp. 217-247. 
39. Nomura, K.; Liu, J.; Padmanabhan, S.; Kitiyanan, B. Nonbridged half-metallocenes containing anionic ancillary donor ligands: New promising candidates as catalysts for precise olefin polymerization. J. Mol. Catal. A: Chem. 2007, 267, 1-29. [CrossRef]

40. Metal Catalysts in Olefin Polymerization; Guan, Z. (Ed.) Topics in Organometallic Chemistry 26; Springer: Berlin, Germany, 2009.

41. Nomura, K. Half-Titanocenes containing anionic ancillary donor ligands as promising new catalysts for precise olefin polymerization. Dalton Trans. 2009, 8811-8823. [CrossRef] [PubMed]

42. Nomura, K.; Zhang, S. Design of vanadium complex catalysts for precise olefin polymerization. Chem. Rev. 2011, 111, 2342-2362. [CrossRef] [PubMed]

43. Makio, H.; Terao, H.; Iwashita, A.; Fujita, T. FI catalysts for olefin polymerization-A comprehensive treatment. Chem. Rev. 2011, 111, 2363-2449. [CrossRef] [PubMed]

44. Delferro, M.; Marks, T.J. Multinuclear olefin polymerization catalysts. Chem. Rev. 2011, 111, $2450-2485$. [CrossRef] [PubMed]

45. Nomura, K.; Liu, J. Half-Titanocenes for precise olefin polymerisation: Effects of ligand substituents and some mechanistic aspects. Dalton Trans. 2011, 40, 7666-7682. [CrossRef] [PubMed]

46. Redshaw, C.; Tang, Y. Tridentate ligands and beyond in group IV metal $\alpha$-olefin homo-/co-polymerization catalysis. Chem. Soc. Rev. 2012, 41, 4484-4510. [CrossRef] [PubMed]

47. Organometallic Reactions and Polymerization; Osakada, K. (Ed.) the Lecture Notes in Chemistry 85; Springer: Berlin, Germany, 2014.

48. McInnis, J.P.; Delferro, M.; Marks, T.J. Multinuclear group 4 catalysis: Olefin polymerization pathways modified by strong metal-metal cooperative effects. Acc. Chem. Res. 2014, 47, 2545-2557. [CrossRef] [PubMed]

49. Tamm, M.; Randoll, S.; Bannenberg, T.; Herdtweck, E. Titanium complexes with imidazolin-2-iminato ligands. Chem. Commun. 2004, 876-877. [CrossRef] [PubMed]

50. Tamm, M.; Randoll, S.; Herdtweck, E.; Kleigrewe, N.; Kehr, G.; Erker, G.; Rieger, B. Imidazolin-2-iminato titanium complexes: Synthesis, structure and use in ethylene polymerization catalysis. Dalton Trans. 2006, 459-467. [CrossRef] [PubMed]

51. Nomura, K.; Fukuda, H.; Apisuk, W.; Trambitas, A.G.; Kitiyanan, B.; Tamm, M. Ethylene copolymerization by half-titanocenes containing imidazolin-2-iminato ligands-MAO catalyst systems. J. Mol. Catal. A: Chem. 2012, 363-364, 501-511. [CrossRef]

52. Nomura, K.; Patamma, S.; Matsuda, H.; Katao, S.; Tsutsumi, K.; Fukuda, H. Synthesis of half-titanocenes containing 1,3-imidazolidin-2-iminato ligands of type, $\mathrm{Cp}^{*} \mathrm{TiCl}_{2}\left[1,3-\mathrm{R}_{2}\left(\mathrm{CH}_{2} \mathrm{~N}\right)_{2} \mathrm{C}=\mathrm{N}\right]$ : Highly active catalyst precursors in ethylene (co)polymerization. RSC Adv. 2015, 5, 64503-64513. [CrossRef]

53. Apisuk, W.; Ito, H.; Nomura, K. Efficient synthesis of cyclic olefin copolymers with high glass transition temperatures by ethylene copolymerization with tetracyclododecene (TCD) using (tert- $\left.\mathrm{BuC}_{5} \mathrm{H}_{4}\right) \mathrm{TiCl}_{2}\left(\mathrm{~N}=\mathrm{C}^{t} \mathrm{Bu}_{2}\right)-\mathrm{MAO}$ catalyst. J. Polym. Sci. Part A: Polym. Chem. 2016, 54, 2662-2667. [CrossRef]

54. Zhao, W.; Nomura, K. Copolymerizations of norbornene, tetracyclododecene with $\alpha$-olefins by half-titanocene catalysts: Efficient synthesis of highly transparent, thermal resistance polymers. Macromolecules 2016, 49, 59-70. [CrossRef]

55. Henschke, O.; Köller, F.; Arnold, M. Polyolefins with high glass transition temperatures. Makromol. Rapid Commun. 1997, 18, 617-623. [CrossRef]

56. Boggioni, L.; Bertini, F.; Zannoni, G.; Tritto, I.; Carbone, P.; Ragazzi, M.; Ferro, D.R. Propene-Norbornene copolymers: Synthesis and analysis of polymer structure by ${ }^{13} \mathrm{C}$ NMR spectroscopy and ab initio chemical shift computations. Macromolecules 2003, 36, 882-890. [CrossRef]

57. Boggioni, L.; Tritto, I.; Ragazzi, M.; Carbone, P.; Ferro, D.R. Propene-Norbornene copolymers: Synthesis and microstructure. Macromol. Symp. 2004, 218, 39-50. [CrossRef]

58. Jung, H.Y.; Hong, S.-D.; Jung, M.W.; Lee, H.; Park, Y.-W. Norbornene copolymerization with $\alpha$-olefins using methylene-bridged ansa-zirconocene. Polyhedron 2005, 24, 1269-1273. [CrossRef]

59. Vanegas, M.E.; Quijada, R.; Galland, G.B. Syndiotactic poly(propene-co-norbornene): Synthesis and properties at low norbornene incorporation. Polymer 2010, 51, 4627-4631. [CrossRef]

60. Hasan, T.; Ikeda, T.; Shiono, T. Random Copolymerization of propene and norbornene with ansa-fluorenylamidodimethyltitanium-based catalysts. Macromolecules 2005, 38, 1071-1074. [CrossRef] 
61. Cai, Z.; Nakayama, Y.; Shiono, T. Living Random Copolymerization of Propylene and norbornene with ansa-fluorenylamidodimethyltitanium complex: Synthesis of novel syndiotactic polypropylene-b-poly(propylene-ran-norbornene). Macromolecules 2006, 39, 2031-2033. [CrossRef]

62. Shiono, T.; Sugimoto, M.; Hasan, T.; Cai, Z.; Ikeda, T. Random copolymerization of norbornene with higher 1-alkene with ansa-fluorenylamidodimethyltitanium catalyst. Macromolecules 2008, 41, 8292-8294. [CrossRef]

63. Cai, Z.; Harada, R.; Nakayama, Y.; Shiono, T. Highly active living random copolymerization of norbornene and 1-alkene with ansa-fluorenylamidodimethyltitanium derivative: Substituent effects on fluorenyl ligand. Macromolecules 2010, 43, 4527-4531. [CrossRef]

64. Hasan, T.; Nishii, K.; Shiono, T.; Ikeda, T. Living polymerization of norbornene via vinyl addition with ansa-fluorenylamidodimethyltitanium complex. Macromolecules 2002, 35, 8933-8935. [CrossRef]

65. Hasan, T.; Ikeda, T.; Shiono, T. Highly efficient Ti-based catalyst systems for vinyl addition polymerization of norbornene. Macromolecules 2004, 37, 7432-7436. [CrossRef]

66. Hasan, T.; Ioku, A.; Nishii, K.; Shiono, T.; Ikeda, T. Syndiospecific living polymerization of propene with [t-BuNSiMe ${ }_{2}$ Flu]TiMe 2 using MAO as cocatalyst. Macromolecules 2001, 34, 3142-3145. [CrossRef]

67. Li, X.; Nishiura, M.; Mori, K.; Mashiko, T.; Hou, Z. Cationic scandium aminobenzyl complexes. Synthesis, structure and unprecedented catalysis of copolymerization of 1-hexene and dicyclopentadiene. Chem. Commun. 2007, 4137-4139. [CrossRef] [PubMed]

68. Suhm, J.; Schneider, M.J.; Mülhaupt, R. Temperature dependence of copolymerization parameters in ethene/1-octene copolymerization using homogeneous rac- $\mathrm{Me}_{2} \mathrm{Si}$ (2-MeBenz[e]Ind) ${ }_{2} \mathrm{ZrCl}_{2} / \mathrm{MAO}$ catalyst. J. Polym. Sci. Part A: Polym. Chem. 1997, 35, 735-740. [CrossRef]

69. Suhm, J.; Schneider, M.J.; Mülhaupt, R. Influence of metallocene structures on ethene copolymerization with 1-butene and 1-octene. J. Mol. Catal. A: Chem. 1998, 128, 215-227. [CrossRef]

70. Zhao, W.; Yan, Q.; Tsutsumi, K.; Nomura, K. Efficient norbornene (NBE) incorporation in ethylene/NBE copolymerization by half-titanocene catalysts containing chlorinated aryloxo ligands. Organometallics 2016, 35, 1895-1905. [CrossRef]

71. Nomura, K.; Oya, K.; Imanishi, Y. Ethylene/ $\alpha$-olefin copolymerization by various nonbridged (cyclopentadienyl)(aryloxy) titanium(IV) complexes-MAO catalyst system. J. Mol. Catal. A: Chem. 2001, 174, 127-140. [CrossRef]

72. Wang, W.; Fujiki, M.; Nomura, K. Copolymerization of ethylene with cyclohexene (CHE) catalyzed by nonbridged half-titanocenes containing aryloxo ligand: Notable effect of both cyclopentadienyl and anionic donor ligand for efficient CHE incorporation. J. Am. Chem. Soc. 2005, 128, 4582-4583. [CrossRef] [PubMed]

73. Liu, J.; Nomura, K. Highly efficient ethylene/cyclopentene copolymerization with exclusive 1,2-cyclopentene incorporation by (cyclopentadienyl)(ketimide) titanium(IV) complexes-MAO catalysts. Adv. Synth. Catal. 2007, 349, 2235-2240. [CrossRef]

74. Nomura, K.; Itagaki, K.; Fujiki, M. Efficient incorporation of 2-methyl-1-pentene in copolymerization of ethylene with 2-methyl-1-pentene catalyzed by nonbridged half-titanocenes. Macromolecules 2005, 38, 2053-2055. [CrossRef]

(C) 2016 by the authors; licensee MDPI, Basel, Switzerland. This article is an open access article distributed under the terms and conditions of the Creative Commons Attribution (CC-BY) license (http://creativecommons.org/licenses/by/4.0/). 